Наташа М. Живић ${ }^{1}$

Прихваћен: 17. фебруар 2021.

https://doi.org/10.46630/phm.13.2021.46

Универзитет у Нишу

Филозофски факултет ${ }^{2}$

Департман за француски језик и књижевност

\title{
РАЗГОВОРНИ ЈЕЗИК У РОМАНУ СТИЛСКЕ ВЕЖБЕ РЕМОНА КЕНОА И ЊЕГОВ ПРЕВОД НА СРПСКИ JЕЗИК
}

У овом раду пажњу усмеравамо на лексику француског разговорног језика, као својственог чиниоца сваког функционалног стила, присутну у роману Ремона Кеноа Стилске вежбе (Raymond Queneau, Les exercices de style, 1947, Paris: Gallimard) и њен превод на српски језик (Remon Keno, Stilske vežbe, 2008, Beograd: Paideia, prevodilac Danilo Kiš).

Истраживање се одвија у неколико етапа. Најпре испитујемо да ли ексцерпирани лексички елементи из оригинала (именице, придеви, глаголи/ глаголске конструкције, прилози) разговорног језика добијају преводне еквиваленте који припадају такође разговорном језику. Затим сагледавамо којим се преводилачким механизмима преводилац служи како би пренео разговорни дух оригиналне слике. Преводилачке технике којима описујемо пренос лексичких елемената јесу оне које је саставио британски теоретичар Питер Њумарк (Peter Newmark, Textbook of Translation, 1988), ослањајући се на поставку канадских лингвиста Жан-Пола Винеа и Жана Дарбелнеа (Jean-Paul Vinay et Jean Darbelnet, Stylistique comparée du français et de l'anglais, 1977).

Полазећи од претпоставке да ће лексика разговорног француског регистра у великој мери бити пренета еквивалентима идентичног регистра, односно разговорног функционалног стила српског језика, долазимо до резултата који нам потврђују полазиште, али исто тако и упућују на то да у се у циљном језику појављују преводни еквиваленти који не припадају разговорном језику.

Кључне речи: лексика, разговорни језик, француски језик, српски језик,

1 natasa.zivic@filfak.ni.ac.rs

2 Овај рад реализује се у оквиру пројекта Романистика и словенски језиии, книжевности и културе у контакту и дисконтакту (Бр. 81/1-17-8-01), који финансирају Филозофски факултет Универзитета у Нишу, Универзитетска агенција за франкофонију (Agence universitaire de la francophonie) и Амбасада Републике Француске у Србији (Ambassade de France en Serbie). 
превођење, преводни еквивалент

\section{1. Увод}

Како функционални стилови језика као и сам језик осликавају систем у константном развитку, док се регистрима пружа могућност прилагођавања језика околностима саме комуникације, приказаћемо лексику, која представља један од чинилаца овог система у развоју, а она карактерише сваки функционални стил па тако и разговорни који чини предмет овог истраживања. Сагледавајући парарелни корпус из правца француског ка српском језику испитаћемо да ли се преводилачким умећем и природом циљног језика успева да се сви оригинални лексички елементи као носиоци духа разговорног језика пресликају у циљну културу.

Проблематиком разговорног језика на релацији францускосрпски (српско-хрватски) језик и обрнуто бави се неколико лингвиста. Наташа Радусин (2006) испитује стилске фигуре: апокопу, аферезу и синкопу. Алма Соколија (2014) истражује париски и сарајевски арго из историјског, лингвистичког и социолингвистичког аспекта. Неке гласовне промене у француском разговорном језику и њихов пренос у српски језик сагледава и Наташа Игњатовић (2015). Проблемима превођења савременог француског жаргона бави се Мирна Синдичић Сабљо (2018).

Иако језици доприносе успостављању идентитета и јединства унутар људских заједница, међу њима постоје разлике и поделе. Осетљиви на различите факторе разликовања који постоје у друштвеној заједници, они рефлектују интерне расцепе који теже географској локализацији или припадности једној друштвеној класи, културном миљеу, професионалној или старосној групи. Једно од централних социолингвистичких питања јесте питање норме или доминантне употребе језика у односу на варијације које чине цео језички систем. (RIGEL, PELA i dr. 2018: 18-19).

Питања на која лингвистика још увек није дала одговоре јесу како да се објасни способност избора и употребе функционалних стилова и прелажење из једног функционалног стила у други, из једног говорног варијетета у други? За пребацивање са једног варијетета на други користи се термин code switching под којим се подразумевају све језичке варијације: стилске, дијалекатске, варијантне, социолекатске. (RADOVANOVIĆ 1986: 167). Не би требало губити из вида то да свака језичка вештина имплицира социјалну вештину. Одабиром регистра на основу саговорника и употребом одређених језика рефлектују се колективне, једностране или реципрочне представе саговорника где се мешају културни и социјални сегмент. Осим језика, одевање, гестикулација, мимика лица, кретање и понашање у простору сачињавају целокупну 
комуникацијску активност коју Радовановић назива говорним догађајем. (RADOVANOVIĆ 1986: 156; SOKOLIJA 2002: 100-101).

Теорија о томе да је језик нејединствен систем који се различитим факторима раслојава везује се за прашку лингвистичку школу. До раслојавања долази према различитим критеријумима, те се бележи: социјално, територијално, индивидуално и функционално-стилско раслојавање (KATNIĆ-BAKARŠIĆ 1999: 19). Р. Бугарски (2005: 20) истиче да се модерни стандардни тј. књижевни језици раслојавају по линијама разграничења социоекономских, образовних, професионалних, узрасних и других група чије потребе осликавају дату културу у виду разних социолеката, функционалних стилова, стручних језика или жаргона. Најзначајније раслојавање српског књижевног језика јесте територијално раслојавање које укључује дијалекатско и варијантно, а затим и социјално раслојавање из којег произлазе различити социолекти и функционално раслојавање које даје разне функционалне стилове језика (STANOJČIĆ, POPOVIĆ 2002: 20). Оно што одликује функционално раслојавање језика јесте инвентар који подразумева лексичке, синтаксичко-семантичке и текстуалне компоненте (RADOVANOVIĆ 1986: 166). Будући да функционални стилови представљају систем у сталном развоју у складу са развитком друштва, класификације се у оквиру тог система унапређују како се и сам комуникацијски чин шири. Руска функционална стилистика наводи функционалне стилове попут научног, публицистичког, књижевноуметничког и разговорног. Б. Тошовић (1988) ових пет наведених стилова обогаћује међустиловима, као што су: сценаристички, есејистички, рекламни, мемоарски, ораторски и епистоларан. Ипак, примарним функционалним стиловима сматрају се научни, журналистички, публицистички, књижевноуметнички, административни и разговорни односно конверзацијски. (KATNIĆ-BAKARŠIĆ 1999: 22-23).

Стандардни француски језик коегзистира са другим језичким варијететима и ствара велики полисистем састављен од константи и варијабли. Осим поделе између писаног и усменог језика, разликују се следећи језички варијетети: а) географски који се односе на говоре и регионалну употребу француског језика у Француској и изван ње; б) ситуациони који упућују на узвишен језик, на свакодневни и фамилијарни; в) технички варијетети односно стручни језик: правни, медицински, технолошки; г) социјални: популарни говор, аргои, као и стандардни француски језик; д) стилистички варијетети односно књижевни, административни или филозофски језик или пак језик медија. (RIGEL, PELA i dr. 2018: 19). Појмове језичког регистра и језичког нивоа не треба мешати у француском језику. Језички нивои одговарају познавању које говорници имају о заједничком француском језику (le français commun) и њиховом нивоу 
образовања. Разликујемо: интелектуални ниво, средњи ниво и популарни ниво. Популарни ниво односи се на слабије образовану популацију која не познаје граматичка правила, а томе слично је и језичка употреба код деце која праве граматичке грешке тог типа. Како регистри упућују на околности комуникације, тако иста особа може користити различите регистре у складу са ситуацијом у којој се налази. Фамилијарни регистар (le registre familier) односи се на свакодневну комуникацију и везује се за говорни коิд, а користе га и најобразованији људи. Фамилијарном регистру припада и пријатељска комуникација као и комуницирање унутар породице. Веома фамилијарним регистром (le registre très familier) служе се вршњачке групе или заједнице засноване на социјалном статусу или интересовању, те је тако овај језички регистар присутан у школи, на факултету, у касарни. Он подразумева известан број речи које се сматрају вулгарним или тривијалним и често су у вези са деловима тела или су пак употребљене тако да човека доводе у везу са животињом. Насупрот томе, негован / узвишен регистар (le registre soigné ou soutenu) везује ce за писани текст, али се појављује и у говору током часа, проповеди или разговора. Веома негован / узвишен регистар (le registre très soigné ou recherché) представља тежњу да се језик разликује од уобичајеног, а нарочито је заступљен у књижевном језику. (GREVIS, GOS 2008: 23-24). Будући да у француском и српском језику постоји разлика у терминологији истих регистара, у овом истраживању користићемо се термином разговорног језика за оба испитивана језика.

Када је реч о српском разговорном језику, он се поистовећује са супстандардним језиком, односно са језиком који стоји насупрот стандардног језика. Разговорни језик на основу неких својих карактеристика подсећа на жаргоне, тј. на језике различитих социјалних група. Употребом специјалне речи и додавањем нових значења постојећим речима, социјалне заједнице стварају језик неразумљив онима који не припадају тој заједници. Такав тајни језик се, осим жаргоном, назива још и аргоом и сленгом. Временом елементи жаргона улазе у стандарни језик ослободивши се притом жаргонског значења. (SILIĆ 2006: 108-109). Гледајући шире, сваки неформални и претежно говорни варијетет неког језика који служи за идентификацију и комуникацију унутар неке друштвено одређене групе по професији, социјалном статусу, узрасту и слично може се назвати жаргоном (BUGARSKI 2003: 9). Жаргон спада у социјално раслојавање језика као врло распрострањена појава у различитим културама и језицима користећи граматичку структуру језика у којем настаје, не нарушавајући притом фонолошке, морфолошке и синтаксичко-семантичке одлике, али своје разликовање он гради на специфичној лексици, користећи се метафоризацијом односно променом постојећег 
значења речи неким другим значењем. Не треба заборавити ни сталну иновативност у креирању жаргонских елемената. (RADOVANOVIĆ 1986: 176-177). Франсоаз Гаде (Françoise Gadet) (2007: 125) скреће пажњу на брзо обнављање лексикона и његову варијабилост у зависности од регије. Јаким везама утврђеним међу члановима одређених заједница долази до њиховог издавајања од осталих заједница и тако се међу поменутим групацијама не успостављају мостови уз помоћ којих би се преносиле информације и језичке иновације.

Разговорни језик обухвата осим усменог и писани говор. Њега карактерише спонтаност и неприпремљеност изражавања којима говорник делује у разговору непосредно и то најчешће дијалогом или монологом када је реч о писаном коду. У овом функционалном стилу налази се највише елемената експресивности и емоционално обојених израза, као и гестова и мимике. Он се још назива и фамилијарним и колоквијалним стилом стандардног језика. Овај стил као социолингвистичка појава није потпуно описан у свету и на нашим просторима што га чини честим „каменом спотицања”. Разговорни стил као и други функционални стилови има своје законитости. Он обилује вулгаризмима, дијалектизмима, регионализмима, барбаризмима и у њему сви поменути појмови фигурирају слободније него у било ком другом функционалном стилу. (SILIĆ 2006: 108-110). Може се рећи и то да вулгаризми, осим употребе у монолошком или дијалошком дискурсу, полако продиру и у језик медија, у сценска и књижевна дела (JOVANOVIĆ 2017: 76). Разговорни стил један је од најекономичнијих и то се уочава на свим нивоима: лексичком, фонолошком, морфолошком и синтаксичком. Због слободнијег реда речи у овом стилу, он се приближава књижевноуметничком стилу који се пак од њега разликује стилизованошћу израза. Овај језички стил бележи и употребу аугментатива, хипокористика и пежоратива. Треба напоменути да се каткад пежоративно значење деминутива употребљава уз пренесено значење са циљем исмевања особе којој се упућује реч, док се пежоративи употребљавају и ради изражавања одмилног значења и у оба случаја важну улогу има и интонација. (SILIĆ 2006: 109-118). Интонацијом, осим изговором и лексиком, један разговор се може окарактерисати нестандардним. Лексику одликују различите специфичности, а поступци остају они које се налазе и у заједничком језику: позајмљивање, скраћивање (апокопа, афереза), редупликација, метафора, метонимија, кодирање (GADE 2007: 124).

Ово истраживање се одвија у неколико фаза. У првој етапи се ексцерпира око 150 лексичких јединица, а то су: именице, глаголи / глаголске конструкције, придеви и прилози који према француском једнојезичном речнику TLFi (Trésor de la langue française informatisé) носе обележје 
pop., fam., vulg., péj., или arg. односно упућују на то да ли испитивана реч припада популарном, фамилијарном или вулгарном језику, или се пак ради о пежоративу или арготизму. Приметно је да се неке лексичке јединице обележавају двојако: fam./pop., fam./vulg., fam./péj., vulg./pop., arg./ fam. што указује на то да је понекад, услед природе сваког живог језика, тешко поставити јасну границу између језичких регистара. Користимо се и двојезичним речником француско-српскохрватског смера Валентина Путанеца. У следећој фази утврђује се да ли ексцерпирани лексички елементи за свој српски еквивалент добијају речи из разговорног функционалног стила. За сагледавање лексикона циљног језика користимо Pечник српскога језика Матице српске и Двосмерни речник српског жаргона и жаргона сродних речи и израза Драгослава Андрића. Преводни стадијум, а уједно и завршница анализе подразумева преводилачке технике уз помоћ којих се описује пренос изворних речи у циљни језик. Користимо се преводним трансформацијама које је изложио Питер Њумарк (Peter Newmark, Textbook of Translation, 1988) ослањајући се у великој мери на поделу техника према Жан-Полу Винеу и Жану Дарбелнеу (Jean-Paul Vinay et Jean Darbelnet, Stylistique comparée du français et de l'anglais, 1977).

\section{2. Анализа корпуса}

Сматра се да се Ремон Кено за писање Стилских вежби инспирисао Баховим делом писаним између 1740. и 1750. године, а састављеним од четрнаест фуга и четири канона. Сваки од контрапунктова сводио се на један те је Кено, након што је одслушао дело, дошао на идеју да направи слично књижевно дело. Говорио је да ће се зауставити на 99. вежби јер то није ни премало ни превише, већ прави грчки идеал. Дело започиње прва вежба којој следи још 98 варијација на исту тему, а она заправо представља причу започету у аутобусу и завршену на станици док две особе разговарају о лоше зашивеном дугмету. Кено се у овом делу игра језиком и каткад измишља свој језик, те се посебним изазовом чини превод оваквог књижевног дела. (LOPEZ MONTAGUT 2012: 2). Захваљујући изврсном писцу и преводиоцу Данилу Кишу, српски читалац има прилику да се упозна са правим ремек-делом савремене француске књижевности.

Вине и Дарбелне (1977: 46-47) преводилачке трансформације деле у две групе: директне и индиректне. Директне јесу оне које се уочавају код језика који деле исте концепције и категорије, а то су дословни превод, калк и позајмљивање. Технику позајмљивања Њумарк назива трансференцијом и у њу спадају транскрипција и транслитерација (NJUMARK 1988: 81-82). Калк представља дословни превод елемената изворних синтагми, док до позајмљивања долази како би се постигао стилистички ефекат и не би ли се пренеле језичке нијансе изворника. 
Индиректним техникама прибегава се онда када се испитивани језици не темеље на структуралном или металингвистичком паралелизму. Тако се одређени стилистички ефекти не транспонују без веће или мање промене реченичног склопа или лексике. У такве преводилачке трансформације спадају: транспозиција, модулација, еквиваленција, натурализација, редукција, експанзија, адаптација и многе друге.

Транспозиција представља промену граматичке категорије у циљном језику, као што је нпр. замена једнине множинским обликом или промена позиције придева, или пак превод герунда неком глаголском именицом и др. Када је реч о модулацији, она се илуструје променом угла сагледавања изворне слике, мењањем категорије мишљења. У модулацију спада изражавање апстрактног појма конкретним, изражавања једног дела другим, замена термина, изражавање пасива активом, времена местом и др. Еквиваленција је техника којом се иста ситуација исказује другачијим термином. Она се уочава код фразеолошких и идиоматских израза или именичких и придевских конструкција. Натурализација указује на прилагођавање изворних речи уобичајеној морфологији циљног језика. Адаптација подразумева употребу преводног еквивалента који препознаје циљна култура будући да је изворна ситуација непозната циљном контексту. Редукцијом се изворни израз скраћује, нпр. придев и именица из изворника у циљном језику постају само именица, док се експанзијом рецимо придеву из оригинала додаје прилог. Термин редукције еквивалентан је термину економије код Винеа и Дарбелнеа, док експанзија одговара њиховој амплификацији (VINE, DARBELNE 1977: 4-16, 46-55; NJUMARK 1988: 81-93).

У приказу преводних механизама, почећемо од оних најфреквентнијих. Примери приказани под А) упућују на преводне еквиваленте разговорног стила, док су примери под Б) они који не припадају разговорном стилу.

Техника која броји највећи део примера јесте модулација, односно промена угла сагледавања оригиналне слике.

A)

(1) Je vis et remarquai un jeune homme et un vieil adolescent assez ridicule et pas mal grotesque : cou maigre et tuyau décharné, ficelle et cordelière autour du chapeau et couvre-chef. (RQf7) - Tada videh i spazih jednog mladića i jednog momka dosta smešnog i prilično grotesknog: vrat dug i izdužena šija, traka i pantlikika oko šešira i klobuka. (RKs6)

(2) Un peu auparavant, rembarré de belle façon une sorte de goujat 
[...]. (RQf19) - Nešto malo pre toga pošteno sam začepio gubicu jednom izlapelcu [...]. (RKs19)

(3) Il y avait aujourd'hui dans l'autobus à côté de moi, sur la plateforme, un de ces morveux [...]. (RQf20) - Danas u autobusu bio je pored mene na platformi jedan od onih šmokljana [...]. (RKs20)

(4) Moi je lui trouvais le cou un peu long à ce jeune homme et aussi bien rigolote cette espèce de tresse qu'il avait autour de son chapeau. (RQf42) - Ja smatram da je taj dasa imao malo suviše dugu šiju i neku blentavu pletenu stvarčicu oko šešira. (RKs46)

(5) Dites-donc, qu'il lui fait, vous pourriez pas faire attention, qu'il ajoute, on dirait, qu'il pleurniche, quvous lfaites essprais, qu'i bafouille, deummarcher toutltemps sullé panards, qu'i dit. (RQf46) $\mathrm{Ej}$, vi, veli on njemu, mogao bi da pripazite, vito namerno, veli, gazite neprestalno po mojim nogama. (RKs51)

(6) Ce cornichon se met à enguirlander un navet qui piétinait ses plates-bandes et lui écrasait ses oignons. (RQf93) - Ljuta paprika poče da štipa za nos i za oči zbog nekog parazita koji joj je izrastao na korenu. (RKs110)

(7) Ce prétentiard se mit à râler parce qu'un vieux con lui piétinait les panards avec une fureur sénile; mais il ne tarda pas à se dégonfler et se débina dans la direction d'une place vide encore humide [...]. (RQf95) - Taj duvadžija počeo je da se dere, jer ga je navodno neki senilac očepio po papcima; no ovaj nije dugo smrdeo nego se zalete kao tele prema jednom praznom sedištu koje je još bilo vlažno od znojavih guzova onoga [...]. (RKs112)

(8) Parmi ce tas de nouilles, je remarquai une grande allumette avec un coup long comme un jour sans pain [...]. (RQf96) - Među tim mešanim mesom spazih jedan veliki ražanj dug kao gladna godina [...]. (RKs113)

(9) [...] pour les bons cons (RQf66) - [...] na dupetron. (RKs80)

Именице tuyau (= цев, туба) и couvre-chef (= шешир, капа) преводе се еквивалентима разговорног језика шија и клобук, који, метафорички посматрано, својим обликом упућују на појмове из изворника. 
Именице goujat (= неотесанац, простак), morveux (= балавац, шмркавац) и придев rigolote (= весео, шаљив) добијају преводне форме излапелач, шмокљан и блентава које, шире посматрајући изворник, преносе нијансе његовог смисла.

Када је реч о глаголу bafouiller (= булазнити, трабуњати), он добија свој преводни еквивалент велити нешто слабијег интензитета изражавања радње. Супстантив cornichon (= корнишон; звекан) се, са друге стране, преводи слободније, номиналном синтагмом из истог контекста льта паприка којој по логици следи глагол пећu, а он представља умногоме модулиран смисао оригиналног глагола enguirlander (= придобити; грдити). Још једна именица из ботаничког лексикона navet (= peпа; тупан) преводи се слободније паразит, а њоме се метафорично преноси смисао.

Супстантив са суфиксом -ard prétentiard (= уображењак), који упућује на пежоративно значење, преноси се фигуративно, еквивалентом дуващuја. Номинална група un vieux con (= стари блесавац, глупан) добија адекват сенилаи који је семантички ближи придеву vieux. Координирани глаголи se dégonfler (= спласнути се; испразнити се) и se débiner (= отићи, одмаглити) преводе се слободније није смрдео него се залете као теле, али без сумње преносе живост оригиналне слике и изражавају природност израза својствен циљној култури. У овом примеру уочава се компарација човека и животиње што је итекако одлика разговорног језика. Именица nouilles (= млитавац) добија адекват мешано месо којим се фигуративно упућује на карактеристике изражене у оригиналу. Како би се пренели ритмика и звучни ефекат, осликани у поглављу под називом Oда, именичка синтагма les bons cons (= прави глупани; блесавци) преноси се измишљеном речју дупетрон која отуд улази у ђачки жаргон и Речник жаргона Драгослава Андрића (KENO 2008: 145). Њумарк истиче важност постизања звучног ефекта који у неким тренуцима игра важнију улогу од самог значења речи (NJUMARK 1988: 58).

Б)

(10) Deux heures plus tard, je le rencontrai de nouveau ; il était en compagnie d'un camarade et parlait chiffons. (RQf8) - Dva sata kasnije ponovo ga sretoh. Bio je u društvu s nekim svojim prijateljem i razgovarao o modi. (RKs7)

(11) Comme je retournais direction rive gauche De nouveau japerçus ce personnage moche Accompagné d'un zèbre, imbécile dandy [...]. (RQf37) - Kako sam se vraćo istim putem, sleva videh opet njega gde besposlen zeva, praćen jednim drugom [...]. (RKs41) 
(12) Ou bien encore on peut toucher du doigt la connerie humaine [...]. (RQf61) - A isto tako čovek može da dodirne prstima ljudske genitalije [...]. (RKs74)

(13) J'étais en train de digérer dans l'autobus de retour lorsque je le vis devant le buffet de la gare Saint-Lazare avec un type tarte [...]. (RQf96) - Pri povratku,upravo sam preživao u autobusu, ponovo ga videh pred bifeom „Kod Bata Laze” sa nekim slastičarem [...]. (RKs113)

(14) Puis on t'y foutrait une tache caca d'oie pour représenter la rage, un triangle rouge pour exprimer la colère et une pissée de vert pour rendre la bile rentrée et la trouille foireuse. (RQf62) - Onda bi još trebalo nacrtati neke mrlje od kakadua da bi se predstavila ljutnja, crveni trougao da bi se predstavio bes i malo zelenog, da bi se pokazala izbljuvana žuč i pokakani kreč. (RKs75)

Израз parler chiffons (= разговарати о одећи) добија свој модулирани адекват разговарати о моди који осликава контекст изворника. Када је реч о примеру un zèbre (= зебра; тип), смисао ове именице се конкретизује преводним еквивалентом друг. Супстантив la connerie (= глупост, бесмислица) доводи се у везу са људским органом гениталије како би се указало на ништавност. Занимљива је синтагма un type tarte (= глуп тип) која се игром речи преноси еквивалентом сластичар скрећући тако пажњу на именицу tarte (= торта). Како би се пренела мелодичност придевске конструкције caca d’oie (= зеленожут), преводилац овај део реченице осликава метафорично, предлошко-падежном везом од какадуа будући да ова животиња јесте представник поменуте нијансе зелене боје. Тако преводилац проналази начин да ослика звучни ефекат оригиналне синтагме и да се тиме преводни еквивалент што више приближи изворнику. С циљем да пренесе боју којом се описује осећај престрављености исказан именицом la trouille (= страх), Данило Киш употребљава метафоричну именицу креч.

Следећа, према учесталости, јесте техника дословног превода која броји еквиваленте из разговорног језика, као и из стандардног.

A)

(15) Le même godelureau! (RQf11) - Tog istog lafa! (RKs10)

(16) Des floppées. (RQf47) - Krkljanac! (RKs52) 
(17) Moi, je lui aurais foutu une baffe à ce salaud qui m’aurait marché sur les pieds. (RQf42) - Ja bih toj bitangi prilepio šamarčinu da je nešto pokušao da meni klacka kosti. (RKs46)

(18) Mais quand on se trouve sur cette plate-forme alors on perçoit quelque chose de plus âpre et de plus rêche qui est la tôle ou la barre d'appui, tantôt quelque chose de plus rebondi et de plus élastique qui est une fesse. (RQf61) - No kad se čovek nađe na toj platformi može da oseti nešto grublje i rapavije, a to je limeni tvrdi rukohvat ili, katkada, mnogo zaobljeniji i elastičniji guz. (RKs74)

(19) Soudain au milieu d'accords [...] où la rage de la contrebasse se mêle à l'irritation de la trompette et à la frousse du basson. (RQf23) - Odjednom među molske akorde [...], gde se bes kontrabasa meša $s$ protestom trompete i sa zortom bas-trube. (RKs76)

(20) Deux heures plus tard comme je me trouvais alors moi-même sur cette impériale japerçus le blanc-bec dont je viens de vous entretenir [...]. (RQf99) - Dva sata kasnije, kako sam se i sam, našao na gornjem spratu, spazih žutokljunca o kome sam vam upravo pričao [...]. (RKs116)

Б)

(21) Ton pleurnichard qui se veut méchant. (RQf6) - Glas piskutav i zloban. RKs5)

(22) Il était en compagnie d'un camarade [...]. (RQf8) - Dva sata kasnije ponovo ga sretoh. Bio je u društvu s nekim svojim prijateljem [...]. (RKs7)

(23) Freluquet au long cou surplombé d'un chapeau cerné d'un galon tressé, roquet rageur, rouspéteur et sans courage qui fuyant la bagarre allas poser ton derrière moissonneur de coups de pieds au cul [...]. (RQf54) - O, zvekane s dugom krivom šijom krunisanom šeširom s pletenom vrpcom, kučko przničava, besna i kukavna koja, pošto si raspalila svađu, povlačiš svoju od udaraca olinjalu zadnjicu [...]. (RKs63)

(24) Tiens, le type qui se trouvait tout à l'heure avec moi dans l'autobus et qui s'engueulait avec un bonhomme. (RQf23) - Gle, onaj tip što se malopre vozio sa mnom u autobusu i koji je psovao onog starkelju. 
(RKs56)

(25) Dites-donc, qu'il lui fait, vous pourriez pas faire attention, qu'il ajoute, on dirait, qu'il pleurniche, quvous lfaites essprais, qu'i bafouille, deummarcher toutltemps sullé panards, qu'i dit. (RQf46) - Ej, vi, veli on njemu, mogao bi da pripazite, vito namerno, veli, gazite neprestalno po mojim nogama. (RKs51)

Проматрање паралелног корпуса указује на то да се у мањем броју примера бележи техника транспозиција, односно замена граматичке категорије.

A)

(26) Alors, on va s'asseoir à l'intérieur, au frais. (RQf34) - Onda on seda, pečen, na jedno slobodno sedište. (RKs38)

(27) Le plus con d'entre ces cons était un boutonneux au sifflet démesuré qui exhibait un galurin grotesque [...]. (RQf95) - Najveći govnar među svim govnarima bio je svakako jedan bubuljičavac sa užasno dugačkom vratinom koji se iskrivio s jednom pišljivom šeširčinom [...]. (RKs112)

(28) Deux heures plus tard, pas de chance, je retombe sur le même con en train de pérorer avec un autre con devant ce monument dégueulasse [...]. (RQf95) - Dva sata kasnije, stvar zaguljena, naletim opet na tog istog govnara i čujem ga kako nešto drobi s nekim drugim seronjom pred onom ništarijom od spomenika [...]. (RKs112)

Промена граматичке категорије из именице у кореспондентни придев осликава се у примеру (26), док се у наредном примеру именица galurin (= шешир) преводи својим кореспондентом у аугментативу щеширчина, форми која се често употребљава у разговорном стилу. Како би изразио смисао придева dégueulasse (= одвратан, гнусан), преводилац Данило Киш служи се именицом сличног значења ништарија.

Б)

(29) Alors, il lui disait, le copain : tu devrais faire mettre un autre bouton à ton pardessus. (RQf44) - Onda mu ovaj reče: trebalo bi da daš da ti se prišije još jedno dugme na kaput. (RKs48)

(30) Comme je retournais direction rive gauche De nouveau japerçus ce personnage moche [...]. (RQf37) - Kako sam se vraćo istim putem, 
sleva Videh opet njega gde besposlen zeva [...]. (RKs41)

Конструкција са поновљеним субјектом il [...] le copain (= он [...] пријатељ) својствена француском језику, преводи се показном заменицом овај. Осим тога, именичка синтагма ce personnage moche (= ружна; досадна особа) преноси се личном заменицом юега којој следи месна реченица где беспослен зева.

Због разлике у синтакси и морфологији испитиваних језика каткад је потребно удаљити се од дословности. Тада је неопходно изворне конструкције обликовати реченичним склоповима који ће адекватно пренети смисао изворника и звучати природно у циљном језику. У том случају прибегава се техници еквиваленције, а она се у приказаним примерима илуструје различитим глаголским контрукцијама, као и преносом стилских фигура аферезе, апокопе и синкопе.

A)

(31) Que, placée sur un long cou, une tête stupide ornée d'un chapeau grotesque vienne à s'enflammer, aussitôt pète la querelle. (RQf34) Ona raspaljuje mozak jednog tikvana sa smešnim šeširom koji je začas spreman da zametne kavgu. (RKs38)

(32) Il finit par s'esbigner lâchement avant que je me décide à lui marcher un peu sur les arpions pour lui faire les pieds. (RQf20) - Laf je, naravno, strugnuo čim mu se dala prilika, tako da nisam stigao još da ga i pošteno očepim po papcima. (RKs20)

(33) D’autant plus qu’après avoir protesté comme cela, il est allé vite s'asseoir dès qu'il a vu une place libre à l'intérieur comme s'il craignait les coups. (RQf55) - Zafrknuo se tim pre što je posle takvi gužve otišao da sedne čim je ugledao jedno slobodno mesto kao da se bojao da ne dobije po njušci. (RKs65)

(34) Tai obus yageur. (RQf39) - Eh se dan tobus tnika. (RKs43)

(35) Je mon dans un aut plein de voya. (RQf40) —Popeo se u jed aut pun put. (RKs44)

(36) Je mtai ds aubus plein dvyageurs. (RQf41) - Peh s u obus pun tika. (RKs45)

Како би се постигле економичност и спонтаност изражавања које карактеришу разговорни језик, неретко се скраћују први или по- 
следњи слог речи или пак средишњи. У том случају говоримо о аферези, апокопи или синкопи. У примерима (34), (35) и (36) уочава се то да преводилац успева да одговарајућим еквивалентима пренесе аферетичне, апокопиране и синкопиране лексичке елементе. Реченица без икаквих стилских интервенција гласи: Je montai dans un autobus plein de voyageurs. (= Попех се у један аутобус пун путника.)

Б)

(37) Mais pour éviter de se faire secouer les puces il cavala vers un terrier abandonné. (RQf97) - Ali, da bi se spasla batina, ona odgalopira u neki pust predeo. (RKs114)

(38) Freluquet au long cou surplombé d'un chapeau cerné d'un galon tressé, roquet rageur, rouspéteur et sans courage qui fuyant la bagarre [...]. (RQf53) - O, zvekane s dugom krivom šijom krunisanom šeširom s pletenom vrpcom, kučko przničava, besna i kukavna koja, pošto si raspalila svađu [...]. (RKs63)

Техника натурализације бележи се такође у нашем паралелном корпусу.

A)

(39) J'ai vu mon type qui discutait avec un copain. (RQf33) - Ugledao sam mog tipa u razgovoru sa nekim drugom. (RKs37)

(40) Il est avec un compagnon qui lui dit : « tu devrais faire ajouter un bouton à ton pardessus. » (RQf12) - Nalazi se kao u društvu nekog svog kompanjona koji mu kaže: „Trebalo bi da daš da ti se prišije jedno dugme na kaput." (RKs11)

Наиме, реч грчког порекла tyре која се у француском језику употребљава у фамилијарном или популарном говору да изрази извесну мушку особу добија свој парњак тип, реч која се користи у српском језику у фигуративном или пежоративном смислу како би изразила настраног, сумњивог човека. Када се ради о речи compagnon, која у фамилијарном језику упућује на веселог, честитог пријатеља, у српском језику добија кореспондент компағон који упућује на ортака, друга, сарадника. И тии и компағон су лексички елементи потпуно уклопљени у морфолошки систем српског језика.

У анализираној грађи уочава се и техника обогаћивања изворног језика зарад постизања нијанси разговорности, а то се постиже преводним механизмом експанзије. 
A)

(41) Enfin après qu'jeuyons paillé, je j’tons un coup d'œil tout alentour de nott peursonne et qu'est-ceu queu jeu voyons-ti pas ? un grand flandrin avec un d'ces cous et un d'ces couv-la-tête pas ordinaires. (RQf103) - Ondati, prije no što će mi jedan ka oficir što li uzet pare za oni biljetić, ja se obrnu, velju da viđu česov se to svijet nagura ovđe ka na pazarni dan, te viđeh jednog grdanti bješe kukala mu majka da se čojek prepadne od njega. (RKs122)

Преводилачким умећем се номинална група un grand flandrin (= велики неспретњаковић) транспонује придевом грданти обогаћеним реченицом кукала му мајка.

Посматрајући паралелни корпус, уочава се да поједине јединице разговорног језика не добијају своје преводне еквиваленте. У таквим примерима, без обзира на њихово изостављање, не нарушава се пишчева ритмика разговорног језика, будући да реченице захваљујући другим елементима одишу духом разговорног језика.

(42) Ce veau se mit à bouillir parce qu'une sorte de croquant (qui en fut $b a b a$ ) lui assaisonnait les pieds poulette. (RQf96) - Ova teletina poče da cvrči, jer je preliše vrelom mašću po papcima. (RKs113)

(43) Rencontré X devant la gare Saint-Lazare qui essaye de gâcher mon plaisir en essayant de me démontrer que ce pardessus est trop échancré et que j’y devrais rajouter un bouton supplémentaire. Il n'a tout de même pas osé s'attaquer à mon couvre-chef. (RQf19) Sretoh onog tipa pred Stanicom Sen Lazar, a on je hteo da mi pokvari zadovoljstvo, dokazujući mi da je na tom mantilu i suviše veliki razrez i da bi stoga trebalo da dodam na njega još jedno dugme. (RKs19)

У примеру (42) уметнута реченица са придевом baba (= забезекнут) изоставља се. У наредном примеру се такође читава реченица са разговорним елементом couvre-chef (= шешир) изоставља, али ова честа реч у роману у другим случајевима добија свој преводни еквивалент: клобук, мајмунада на тикви, капелин.

\section{3. Закључак}

Анализа паралелног корпуса указује на то да се већински део изворног разговорног лексикона преноси еквивалентима разговорног фунционалног стила. Истраживање указује и на то да се у једном делу посматраних примера појављују преводни еквиваленти који не припа- 
дају разговорном језику. И у једном и у другом случају уочавају се преводилачке технике које су по учесталости следеће: модулација, дословни превод, транспозиција, еквиваленција, натурализација, експанзија.

Модулацијом се осликава пренос оригиналних лексичких елемената и то тако што се њихово значење сагледава шире или на тај начин што се метафором, стилском фигуром својственом разговорном језику, упућује на схватање смисла изворника (Ce cornichon se met à enguirlander un navet qui piétinait ses plates-bandes et lui écrasait ses oignons. - Ljuta paprika poče da štipa za nos i za oči zbog nekog parazita koji joj je izrastao na korenu; Il était en compagnie d'un camarade et parlait chiffons. - Bio je u društvu s nekim svojim prijateljem i razgovarao o modi.). Како би пресликао атмосферу француског романа у српски језички систем, преводилац се служи техником дословног превода именичких, глаголских и придевских конструкција (Des floppées. - Krkljanac!; Ton pleurnichard qui se veut méchant. - Glas piskutav i zloban.). Транспозицијом се мења граматичка категорија именице у придев и обратно, или се пак француска синтакса поједностављује српским заменичким облицима (Alors, on va s'asseoir à l'intérieur, au frais. - Onda on seda, pečen, na jedno slobodno sedište.; Alors, il lui disait, le copain : tu devrais faire mettre un autre bouton à ton pardessus. - Onda mu ovaj reče: trebalo bi da daš da ti se prišije još jedno dugme na kaput.). Како би се добиле глаголске конструкције усклађене са природом циљног језика, преводилац прибегава техници еквиваленције. Еквиваленцијом се, исто тако, преносе и апокопиране, синкопиране и аферетичне лексичке јединице (Je mon dans un aut plein de voya. - Popeo se u jed aut pun put.; Mais pour éviter de se faire secouer les puces il cavala vers un terrier abandonné. - Ali, da bi se spasla batina, ona odgalopira u neki pust predeo.). Ово истраживање указује и на прожимање двеју испитиваних култура и то тако што се натурализацијом илуструје потпуно морфолошко уклапање страних речи у српски лексички систем (Il est avec un compagnon qui lui dit [...]. - Nalazi se kao u društvu nekog svog kompanjona koji mu kaže [...]). Зарад постизања још ефектније експресивности разговорног језика Данило Киш експанзијом обогаћује изворни текст ([...] un grand flandrin avec un d'ces cous et un d'ces couv-la-tête pas ordinaires. - [...] viđeh jednog grdanti bješe kukala mu majka da se čojek prepadne od njega.). Треба споменути и то да се понегде неки сегменти разговорног текста не преносе, али то не нарушава целокупну слику будући да циљни израз у сваком случају обилује разговорним лексиконом (Ce veau se mit à bouillir parce qu'une sorte de croquant (qui en fut $b a b a$ ) lui assaisonnait les pieds poulette. - Ova teletina poče da cvrči, jer je preliše vrelom mašću po papcima.).

Овим истраживањем указали смо на то да, без обзира на различитост природе испитиваних језика, говорници и једног и другог језика 
негују веома сличне слике света које се рефлектују кроз подударање карактеристичне употребе разговорног језика. Оно што указује на богатство сваког језика јесте његова могућност да се изрази кроз себи својствене нијансе, а оне се и те како осликавају у продуктивности и иновативности разговорног језика.

\section{Цитирана литература}

ANDRIĆ 2005: ANDRIĆ, Dragoslav. Dvosmerni rečnik srpskog žargona i žargona srodnih reči i izraza. Drugo, znatno dopunjeno izdanje. Beograd: Zepter Book World Dragoslav Andrić, 2005. [orig.] АНДРИЋ, Драгослав. Двосмерни речник српског жаргона и жаргона сродних речи и израза. Друго, знатно допуњено издање. Београд: Zepter Book World Драгослав Андрић, 2005.

BUGARSKI 2003: BUGARSKI, Ranko. Žargon. Lingvistička studija. Beograd: Biblioteka XX vek, 2003.

BUGARSKI 2005: BUGARSKI, Ranko. Jezik i kultura. Beograd: Biblioteka XX vek, 2005.

GADE 2007 : GADET, Françoise. La variation sociale en français. Nouvelle édition revue et augmentée. Paris : Orphys, 2007.

GREVIS, GOS 2008: GREVISSE, Maurice et André Goosse. Le bon usage. Grammaire française 14 ${ }^{\text {ème }}$ édition. Bruxelles : De Boeck/Duculot, 2008.

JOVANOVIĆ 2017: JOVANOVIĆ, Ivan. „Vulgarizmi u diskursu telefonskih razgovora: jedan primer iz ruralne sredine". Opscena leksika u srpskom jeziku. Zbornik radova sa istoimenog naučnog skupa. Priredila Jordana Marković, Filozofski fakultet Niš (2017): 75-96. [orig.] ЈОВАНОВИЋ, Иван. „Вулгаризми у дискурсу телефонских разговора: један пример из руралне средине”. Опсиена тексика у српском језику. Зборник радова са истоименог научног скупа. Приредила Јордана Марковић, Филозофски факултет Ниш (2017): 75-96.

KATNIĆ-BAKARŠIĆ 1999: KATNIĆ-BAKARŠIĆ, Marina. Lingvistička stilistika. Budapest: Open Society Institute, Center for Publishing Development, Electronic Publishing Program, 1999.

IGNJATOVIĆ 2015: IGNJATOVIĆ, Nataša. „O nekim glasovnim promenama u francuskom razgovornom jeziku i o njihovom prenošenju u srpski jezik". Jezik $i$ književnost u kontaktu i diskontaktu. Tematski zbornik radova sa naučnog skupa „Nauka i savremeni univerzitet 4". Glavni i odgovorni urednik Bojana Dimitrijević. Filozofski fakultet Univerziteta u Nišu (2015): 343-356. [orig.] ИГЊАТОВИЋ, Наташа. „О неким гласовним променама у француском разговорном језику и о њиховом преношењу у српски језик”. Језик и книжевност у контакту и дисконтакту. Тематски зборник радова са научног скупа „Наука и савремени универзитет 4”. Главни и одговорни уредник Бојана Димитријевић. Филозофски факултет Универзитета у Нишу (2015): 343-356.

LOPEZ MONTAGUT 2011 : LÓPEZ MONTAGUT, Aina. «Sur «Les exercices de style » de Raymond Queneau. » Les traductions vieillissent-elles ?. International 
symposium organized by Université Paris Sorbonne - Paris IV. Colegio de España, Paris. (10-12 Octobre 2011) : 1-21.

NJUMARK 1988: NEWMARK, Peter. Textbook of Translation. New York: Prentice Hall International ELT, 1988.

PUTANEC 2003: PUTANEC, Valentin. Francusko-hrvatski rječnik. Zagreb: Školska knjiga, 2003.

RADOVANOVIĆ 1986: RADOVANOVIĆ, Milorad. Sociolingvistika. Novi Sad: Dnevnik, Književna zajednica Novog Sada, 1986.

RADUSIN 2006: RADUSIN, Nataša. „Afereza, sinkopa i apokopa u razgovornom francuskom i srpskom jeziku”. Godišnjak Filozofskog fakulteta u Novom Sadu, XXXI (2006): 411-425.

SILIĆ 2006: SILIĆ, Josip. Funkcionalni stilovi hrvatskoga jezika. Zagreb: Disput, 2006. SINDIČIĆ SABLJO 2018: SINDIČIĆ SABLJO, Mirna. „Kako prevoditi suvremeni francuski žargon? Traduktološka analiza hrvatskog prijevoda romana Volim sutra Faize Guene”. A journal of literature, culture and literary translation, 8 (2018), 2: 1-26.

SOKOLIJA 2002: SOKOLIJA, Alma. "Études constrastives des argot de Sarajevo et de Paris. Aspects méthodologiques. " Presses Universitaires de France / La linguistique. 2002/1 Vol. 38 (2002) : 99-112.

SOKOLIJA 2014: SOKOLIJA, Alma. L'argot parisien et l'argot Sarajevien avec les dictionnaires. Description et comparaion historiques, linguistiques et sociolinguistiques. <http://www.ff-eizdavastvo.ba/Books/1\%E2\%80\%99Argot_parisien_et_1\%E2\%80\%99argot_sarajevien_avec_les_dictionnaires.pdf $>1$. X 2020.

STANOJČIĆ, POPOVIĆ 2004: STANOJČIĆ, Živojin i Ljubomir POPOVIĆ. Gramatika srpskog književnog jezika. Beograd: ZUNS, 2004. [orig.] СТАНОЈЧИЋ, Живојин и Љубомир, ПОПОВИЋ. Граматика српског книжевног језика. Београд: ЗУНС, 2004.

TLFi: Le Trésor de la langue française informatisé. <http://atilf.atilf.fr/tlf.htm>.

TOŠOVIĆ 2002: TOŠOVIĆ, Branko. Funkcionalni stilovi. Beograd: Beogradska knjiga, 2002. [orig.] ТОШОВИЋ, Бранко. Функционални стилови. Београд: Београдска књига, 2002.

VINE, DARBELNE 1977: VINAY, Jean et Jean-Paul DARBELNET. Stylistique comparée du français et de l'anglais. Paris: Didier, 1977.

VUJANIĆ, GORTAN-PREMK i dr. 2007: VUJANIĆ, Milica i Darinka GORTANPREMK, Milorad Dešić, Rajna Dragićević, Miroslav Nikolić, Ljiljana Nogo, Vasa Pavković, Nikola Ramić, Rada Stijović, Milica Tešić, Egon Fekete. Rečnik srpskoga jezika. Novi Sad: Matica srpska, 2007. [orig.] ВУЈАНИЋ, Милица и Даринка ГОРТАН-ПРЕМК, Милорад Дешић, Рајна Драгићевић, Мирослав Николић, Љиљана Ного, Васа Павковић, Никола Рамић, Рада Стијовић, Милица Тешић, Егон Фекете. Речник српскога језика. Нови Сад: Матица српска, 2007. 
(RQf): QUENEAU 1947 : QUENEAU, Raymond. Les exercices de style. Paris: Gallimard, 1947. <http://www.desmotsetdesidees.fr/medias/files/exercices-destyle.pdf $>1$. II 2021.

(RKs): KENO 2008 : KENO, Remon. Stilske vežbe. Prevod Danilo Kiš. Beograd: Paidea, 2008.

Nataša M. Živić

\section{LA LANGUE FAMILIÈRE DANS LE ROMAN LES EXERCICES DE STYLE DE RAYMOND QUENEAU ET SA TRADUCTION EN SERBE}

Dans cet article, notre objectif est le lexique du français familier, présent dans le roman Les exercices de style de Raymond Queneau (Paris: Gallimard, 1947) et sa traduction serbe faite par le traducteur et écrivain Danilo Kiš (Beograd : Paideia, 2008). Cette recherche se déroule en plusieurs étapes. Tout d’abord, nous examinons si les éléments lexicaux du français familier (noms, adjectifs, verbes / constructions verbales, adverbes) se transfèrent par des équivalents appartenant également à la langue familière. Ensuite, nous analysons les techniques traductologiques utilisées par le traducteur pour transmettre l'image originale. Ces mécanismes de traduction des éléments lexicaux sont ceux élaborés par le théoricien britannique Peter Newmark (Textbook of Translation, 1988) sappuyant sur les linguistes canadiens Jean-Paul Vinay et Jean Darbelnet (Stylistique comparée du français et de l'anglais, 1977). Partant de l'hypothèse que le vocabulaire du registre français familier sera transféré par les équivalents du registre identique, nous arrivons à des résultats qui confirment notre point de départ, mais indiquent aussi les équivalents traductologiques qui ne font pas partie de la langue familière.

Mots clés: lexique, langue familière, langue française, langue serbe, traduction, équivalent 